\title{
Os espantalhos desamparados de Manuel Bandeira
}

\author{
MARCUS V. MAZZARI
}

\section{A mitologia da infância}

$\mathrm{N}$

A BELA e misteriosa narrativa "Josefina, a cantora ou O povo dos camundongos", que Franz Kafka escreve pouco antes da morte, a arte do "canto" da ratinha Josefina é associada em dado momento à "pobre, curta infância", a algo de uma "felicidade perdida, não mais recobrável". Os termos parecem contraditórios, mas fazem pleno sentido referidos às circunstâncias da vida infantil na comunidade em que Kafka projeta e tematiza o enigma da arte e de sua relação com a sociedade (1).

O atributivo "pobre" também poderia aplicar-se à meninice evocada por Raul Pompéia em seu romance $O$ Ateneu, ainda que no início esta assome à memória do eu-narrador banhada pelo "ouro da manhã", isto é, durante o breve período de proteção e aconchego na "estufa de carinho que é o regime do amor doméstico": trata-se dos momentos de sonhos e devaneios do menino Sérgio junto ao lago do jardim de casa, à "sombra dos tinhorões, na transparência adamantina da água..." (2).

E não se poderia reconhecer nessas imagens de "transparência adamantina" a fonte arquetípica e inesgotável em que vem haurir toda criação literária empenhada em recordar uma plenitude perdida ou, inversamente, em denunciar os ultrajes contra o mundo da criança? A resposta afirmativa teria o apoio de não poucas reflexões teóricas voltadas, com sensibilidade e rigor, para esse momento auroral da existência, em que - como sugerem versos de Manuel Bandeira - o desejo de alcançar o céu já significa habitá-lo: "Não sente a criança / Que o céu é ilusão: / Crê que o não alcança / Quando o tem na mão.”

No início de seu estudo sobre "poesia ingênua e sentimental”, Friedrich Schiller refere-se a momentos na vida do adulto em que o encontro com a "natureza humana" idealmente presente na criança vem acompanhado de profunda comoção. Vivenciamos, nesses raros momentos, a mesma intuição da plenitude suscitada pelo gorjeio dos pássaros, pela contemplação de uma flor ou de uma árvore, de uma fonte ou mesmo de uma simples pedra coberta pelo musgo... Levanta-se em nós, assim, a "idéia" de uma vida singela e ativa, da existência autônoma, guiada por leis próprias, no sentido da eterna unidade do ser consigo mesmo - a mesma idéia, enfim, que se vislumbra no universo das crianças: 
"São o que nós fomos; são o que devemos vir a ser de novo. Fomos natureza como elas, e nossa cultura deve nos reconduzir à natureza pelo caminho da razão e da liberdade. São, portanto, expressão da nossa infância perdida, que para sempre permanece como aquilo que nos é mais precioso; por isso, enchem-nos de uma certa melancolia. Ao mesmo tempo, são expressões de nossa suprema completude no Ideal, transportando-nos, por isso, a uma sublime comoção" (3).

Concepção semelhante da infância subjaz à arquifamosa reflexão de Marx a respeito das relações paradoxais entre o grau de desenvolvimento material de uma sociedade e o nível de suas manifestações artísticas. O esforço de compreender o fascínio imorredouro exercido pela arte grega (e, em particular, a epopéia homérica), leva Marx ao estabelecimento de um paralelo entre o que considera a "infância histórica" da humanidade e a infância de cada existência humana:

"Um homem não pode voltar a ser criança, ou ele se tornará pueril. Mas não o alegra a ingenuidade da criança, e não deve ele próprio aspirar a reproduzir a verdade infantil num nível superior? Não se revigora na natureza infantil o caráter próprio de toda época em sua verdade natural? Por que a infância histórica da humanidade, onde desabrochou da maneira mais bela, não deveria exercer eterno encanto como um estágio que nunca mais retorna?" (4)

Tendo experimentado portanto, em seus primeiros anos, a percepção animista, mágica, que guardaria afinidades com a correlata fase filogenética de inocência e plenitude (fase "mitológica", diz o pensador materialista; "ingênua", na perspectiva idealista de Schiller), o homem adulto será eternamente suscetível ao encanto que emana das primeiras produções artísticas do Ocidente.

Por mais surpreendente que possa parecer, podemos encontrar em Manuel Bandeira complementação das mais expressivas para o paralelismo traçado por Marx, e precisamente no trecho do Itinerário de Pasárgada (final do primeiro capítulo) em que rememora a quadra de sua vida, dos seis aos dez anos, em que se constituiu a sua própria "mitologia", plena de figuras com "a mesma consistência das personagens dos poemas homéricos". As argumentações seguem direções opostas: em Marx, a incursão pela infância individual subordina-se à tentativa de apreender e especificar relações entre as esferas social e artística, como volta a evidenciar-se no final da passagem: "O encanto de sua arte não está para nós em contradição com o nível social não-desenvolvido no qual ela vicejou. É antes o resultado deste e está indissoluvelmente ligado ao fato de que as condições sociais imaturas nas quais ela se originou, e apenas nas quais poderia ter-se originado, não podem retornar nunca mais.”

Em Bandeira, é a reflexão sobre a força poética e vital contida nesses áureos tempos de sua meninice que o faz transitar para a "infância histórica da humanidade": "A Rua da União, com os quatro quarteirões adjacentes limita- 
dos pelas ruas da Aurora, da Saudade, Formosa e Princesa Isabel, foi a minha Tróada; a casa de meu avô, a capital desse país fabuloso. Quando comparo esses quatro anos de minha meninice a quaisquer outros quatro anos de minha vida de adulto, fica espantado do vazio desses últimos em cotejo com a densidade daquela quadra distante" (5).

\section{A infância pobre em Manuel Bandeira}

Revelação viva e epifânica dessa quadra de felicidade mítica, em que, para além da passagem do tempo, "tudo lá parecia impregnado de eternidade" (6), aflora no poema "Evocação do Recife", que consta do quarto livro de poesia de Manuel Bandeira, Libertinagem. Outra obra-prima que Bandeira extraiu da mina dessa sua "Tróada" recifense é o poema "Profundamente" (também de Libertinagem), que a análise de Davi Arrigucci Jr. iluminou de diferentes ângulos, ressaltando porém a força simbólica com que o poeta retoma e atualiza um tópico tão antigo como o do ubi sunt?, relacionando-o não só com a sua história de vida, mas também com o processo de modernização da sociedade brasileira (7).

Sabemos, contudo, que a tematização da infância na obra de Manuel Bandeira não se deu apenas mediante o ato de recordar a própria experiência individual. Pois ainda antes da "Evocação do Recife" ou de "Profundamente", vieram poemas que se assentam na observação do mundo da infância, ou melhor dizendo, poemas em que Bandeira, mais ainda do que observar, compartilha liricamente dos acontecimentos tematizados. Expressivo momento dessa atitude encontra-se no livro $O$ ritmo dissoluto, precisamente nos poemas "Meninos carvoeiros", "Na Rua do Sabão" e ainda "Balõezinhos", que fecha o livro com a imagem dos "menininhos pobres" - presentes na metonímia especular dos "olhos muito redondos" fixos nos "grandes balõezinhos muito redondos" - compondo em torno do vendedor loquaz, numa feira de arrabalde, "um círculo inamovível de desejo e espanto".

Do ponto de vista formal, podemos destacar em primeiro lugar, como traço comum a esses três poemas, o predomínio do verso-livre, que na trajetória poética de Bandeira pode ser considerado índice de seu acercamento ao prosaico, à vida cotidiana, aprofundando a ruptura com o início parnasiano-simbolista. Os poemas constam, como já ficou dito, de O ritmo dissoluto, o primeiro dos quatro livros (incluindo-se a prosa das Crônicas da Província do Brasil) que escreve na rua do Curvelo, para onde o poeta - já marcado pela pobreza, pela solidão e pela tuberculose - muda-se em 1920. Foi publicado o livro em 1924 e, conforme reconstitui Bandeira no Itinerário de Pasárgada, teve recepção controversa por parte dos admiradores de sua poesia, como se exemplifica, por um lado, com Adolfo Casais Monteiro, para quem "muitas são as poesias sem ritmo de espécie alguma; mais do que ritmo dissoluto portanto..."; e, por outro lado, Octávio de Faria, que vislumbra aí o momento "em que o poeta vencendo as últimas barreiras da sujeição a regras que o tolhem demais, atinge a 
sua forma mais agradável." O próprio Bandeira, ainda segundo a reconstituição de seu Itinerário, considera O ritmo dissoluto um "livro de transição", e isto tanto para a "afinação poética" conquistada no âmbito do verso-livre e dos versos rimados e metrificados, como também, quanto à expressão de sentimentos e idéias, para a "completa liberdade de movimentos, liberdade de que cheguei a abusar no livro seguinte, a que por isso mesmo chamei Libertinagem" (8).

Se $O$ ritmo dissoluto representa assim o primeiro fruto da experiência de Bandeira na rua do Curvelo, então é legítimo supor que essa influência "mundana", oriunda da rua, tenha contribuído igualmente para a constituição da temática desdobrada nos poemas "Na Rua do Sabão", "Meninos carvoeiros" e "Balõezinhos". O próprio Itinerário de Pasárgada fornece indicações nesse sentido, quando reproduz por exemplo a seguinte observação de Ribeiro Couto, feita no discurso com que saudou, em 1940, o ingresso do amigo na Academia Brasileira de Letras: "Das vossas amplas janelas, tanto as do lado da rua em que brincavam crianças, como as do lado da ribanceira, com cantigas de mulheres pobres lavando roupa nas tinas de barrela, começastes a ver muitas coisas. $\mathrm{O}$ morro do Curvelo, em seu devido tempo, trouxe-vos aquilo que a leitura dos grandes livros da humanidade não pode substituir: a rua."

E, caracterizando em seguida a vista que tinha, de sua nova casa, sobre o ambiente do Curvelo, as palavras de Bandeira elucidam de maneira ainda mais particularizada o tema da infância pobre, pois enquanto pelo "fundo da casa" podia observar a "pobreza mais dura e mais valente", o lado da frente traçava a "zona de convívio com a garotada sem lei nem rei que infestava as minhas janelas, quebrando-lhes às vezes as vidraças, mas restituindo-me de certo modo o meu clima de meninice na Rua da União em Pernambuco." E na seqüência, como síntese dessas vivências e observações: "Não sei se exagero dizendo que foi na Rua do Curvelo que reaprendi os caminhos da infância" (9).

De dois testemunhos dessa aprendizagem do poeta adulto, "Meninos carvoeiros" e "Na Rua do Sabão", é possível acompanhar também um pouco de sua gênese mediante cartas trocadas com Mário de Andrade, já que as de Bandeira foram acompanhadas, por duas vezes, dos manuscritos dos poemas, com variantes bastante interessantes em relação à versão definitiva. Em carta escrita provavelmente no dia 22 de maio de 1923, Mário pede permissão - e já em seguida responde pelo amigo - para publicar "Na Rua do Sabão" no último número da revista Klaxon (10), e num post scriptum à carta de 7 de junho do mesmo ano lê-se a seguinte observação: "Esqueci de dizer do teu poema 'Os meninos carvoeiros' que só a 'Rua do Sabão' o ultrapassa. É UMA DELíCIA.”

A próxima carta que Mário dirige ao amigo, datada de 5 de agosto, volta a referir-se a esses dois poemas, mas agora como que para "repreender" o sentimento merencório e autocomiserativo que Bandeira colocara numa observação relativa ao seu relacionamento com a tuberculose: 


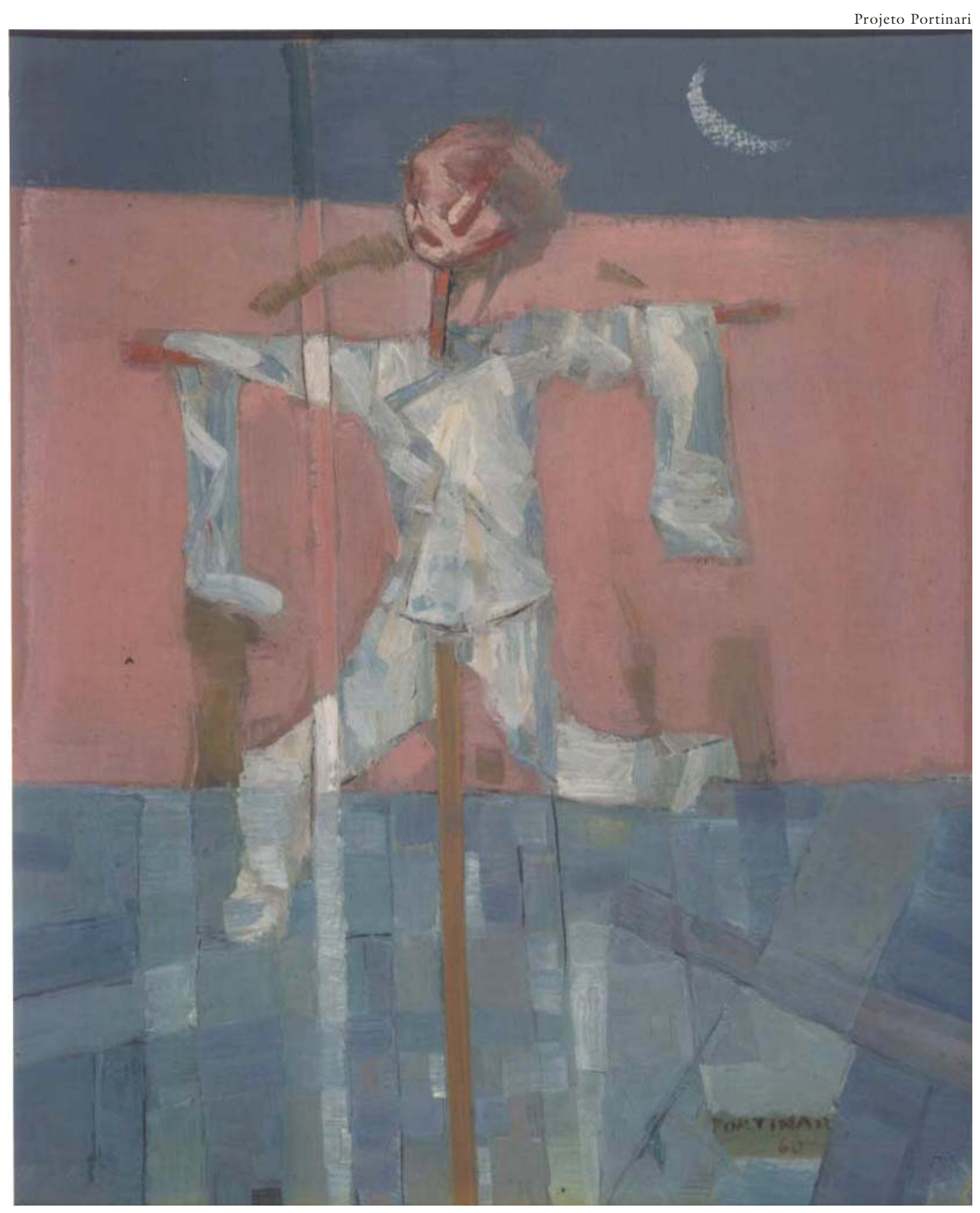

\section{Espantalho}

1960

Pintura a têmpora e óleo/tela

$47 \times 38 \mathrm{~cm}$

Coleção Particular - São Paulo - SP 
"Mas erras enormemente, Manuel, quando dizes como na tua última carta 'Hoje sou ironicamente, sarcasticamente tísico'. Não o és mais. Ao menos 'sarcasticamente'. Nem o foste nunca, propriamente. Eu sei. Ironicamente, inda vá. Mas quem escreve 'Os meninos carvoeiros' e a 'Rua do Sabão' não é mais sarcasticamente tísico, é amorosamente tísico. E o 'Bonheur lyrique'? Eis aí, meu amigo, onde estamos hoje, tu e eu" (11).

Já uma leitura inicial poderia fixar, como traço comum mais geral aos dois poemas, a "temática" da infância pobre. Mas, num segundo passo, também já seria necessário atentar às diferenças no tratamento lírico que o poeta dispensa à sua observação (não importa se imaginária ou real) dos pequenos trabalhadores de carvoaria e dos acontecimentos protagonizados pelas crianças pobres da rua do Sabão. Vale observar aqui, em primeiro lugar, que o gesto "amorosamente tísico" a que se refere Mário de Andrade evidencia-se com mais intensidade no poema que também considera superior. Entretanto, isto não deve significar que o poeta tenha colocado menos "amorosidade" na observação do trabalho dos carvoeiros, essas “crianças raquíticas" que - a despeito daquilo que o poema silencia - parecem integradas na "madrugada ingênua" e como que fundidas com os "burrinhos descadeirados" que vão tocando: "adoráveis carvoeirinhos que trabalhais como se brincásseis!" Pois tal como nos versos que acompanham a serena ascensão do balãozinho na rua do Sabão, também aqui a empatia do poeta com os seres de sua observação plasma-se na qualidade dos versos livres que se amoldam ao ritmo da marcha dos meninos, mais composta na ida, mais dissoluta na volta:

"Quando voltam, vêm mordendo num pão encarvoado, Encarapitados nas alimárias,

Apostando corrida,

Dançando, bamboleando nas cangalhas como espantalhos desamparados!”

Seria tarefa de uma análise mais detalhada revelar aqui em que medida a estrutura rítmica e sonora desses versos “prosaicos”, também a precisão vocabular que surpreende por um refinamento que jamais resvala no pedantismo, expressam, já na imanência da linguagem, a profunda empatia do poeta com os meninos carvoeiros, que refulgem ao final na esvoaçante imagem dos "espantalhos desamparados". Tudo isso torna difícil, numa comparação entre os dois poemas, dar a primazia a um ou a outro. Mas talvez o juízo de Mário deva-se sobretudo à estrutura formal mais elaborada que se verifica no poema "Na Rua do Sabão"; além disso é este que evidencia de maneira mais explícita, como se verá a seguir, o poeta que seria, acima de tudo, “amorosamente tísico". 


\section{Na Rua do Sabão}

Cai cai balão

Cai cai balão

Na Rua do Sabão!

O que custou arranjar aquêle balãozinho de papel!

Quem fềz foi o filho da lavadeira.

Um que trabalha na composição do jornal e tosse muito.

Comprou o papel de sêda, cortou-o com amor, compôs os gomos oblongos... Depois ajustou o morrão de pez ao bocal de arame.

Ei-lo agora que sobe - pequena coisa tocante na escuridão do céu.

Levou tempo para criar fôlego.

Bambeava, tremia todo e mudava de côr.

A molecada da Rua do Sabão

Gritava com maldade:

Cai cai balão!

Sùbitamente, porém, entesou, enfunou-se e arrancou das mãos que o tenteavam. E foi subindo...

$$
\text { para longe... }
$$

serenamente..

Como se o enchesse o soprinho tísico do José.

Cai cai balão!

A molecada salteou-o com atiradeiras

$$
\begin{aligned}
& \text { assobios } \\
& \text { apupos } \\
& \text { pedradas. }
\end{aligned}
$$

Cai cai balão!

Um senhor advertiu que os balões são proibidos pelas posturas municipais.

Ele foi subindo...

muito serenamente...

$$
\text { para muito longe... }
$$

Não caiu na Rua do Sabão.

Caiu muito longe... Caiu no mar - nas águas puras do mar alto. 


\section{O balão em ascensão}

Procedendo inicialmente a um comentário descritivo mais geral, assinalese de imediato que o poema se estrutura em versos livres, cuja técnica ia sendo apurada nesse mesmo livro que, como se viu, o próprio poeta considerará depois de "transição". No entanto, o poema abre-se com a citação de uma cantiga junina, anunciando assim, de chofre, um motivo popular: "Cai cai balão / Cai cai balão / Na Rua do Sabão!” Predominam no poema os versos brancos, mas se tem na abertura uma rima simples e ingênua, própria de cantigas populares e folclóricas. Observe-se ainda que o versinho "Cai cai balão" ocorrerá mais três vezes, constituindo-se em espécie de leitmotiv que exprime a tendência contrária ao acontecimento celebrado no poema. Mas, se é possível falar em "acontecimento celebrado" no poema, então pode-se também inferir daí que este possui um argumento narrativo, e até mesmo, indo um pouco além, que "Na Rua da Sabão" está impregnado - a exemplo de outros célebres poemas de Bandeira, como "Gesso", "Profundamente", "O cacto" - de elementos épicos, assumindo assim uma atitude para a qual a perspectiva didática de um Wolfgang Kayser teria a designação de "enunciação lírica".

Nesse sentido, a primeira aproximação ao poema se poderia dar mediante a consideração de sua estratificação temporal - da dimensão, portanto, em que a narrativa poética é desdobrada. De que forma essa exposição lírica de uma história que se desenvolve no tempo (mas também no espaço) concebe e articula entre si os diferentes planos temporais?

O primeiro e mais remoto apresenta, de maneira sintética, o trabalho de confecção; ressalta inicialmente a dificuldade que foi "arranjar aquele balãozinho de papel" e estende a descrição até o ajuste do "morrão de pez ao bocal de arame". O artífice é referido apenas, de forma indireta, como "o filho da lavadeira", a que se segue complemento introduzido pelo artigo indefinido: "um que trabalha na composição do jornal e tosse muito".

O segundo plano temporal seria aquele em que o eu-lírico - o sujeito da enunciação lírica, a partir de cuja perspectiva e em cujo tom o poema se organiza (12) - vem situar-se mais explicitamente, como indicia o verso "Ei-lo agora que sobe - pequena coisa tocante na escuridão do céu." Observe-se, porém, que logo após este verso, o único referente à história do balão que traz o verbo no presente, recua-se ligeiramente no tempo para falar de uma outra dificuldade, que foi a de alçar vôo, de 'entesar, enfunar-se e arrancar das mãos que tenteiam'. Contudo, se nessa dimensão houve, após o momento da presentificação ("Ei-lo agora que sobe"), um recuo no tempo, haverá também um avanço para além deste momento, que primeiro se realiza nos versos: 
E foi subindo... para longe...

serenamente...

e, em seguida, reiterado e intensificado pelo advérbio:

Ele foi subindo...

muito serenamente...

para muito longe...

Já pela configuração visual dos versos, que sugere o movimento de expansão, pelo uso das reticências (ou pontos de suspensão), sugerindo o fluxo do processo, e também pela reiteração intensificada dos três primeiros versos, $\mathrm{O}$ movimento de ascensão no espaço, por conseguinte também a seqüência temporal até então empiricamente reconstituível, entram no ilimitado, no indeterminado, não mais apreensível ao eu que se situara na dimensão dos acontecimentos narrados.

Todavia, a última palavra do poema não reside na notícia da vigorosa e serena ascensão do balãozinho, até esfumar-se, para os olhos que o acompanham, no espaço infinito. Rompendo esse avanço no plano da presentificação, que tenderia aliás à continuidade plena - lembrem-se aqui as definições da lírica enquanto "sensação que se encerra no presente" - diz o verso final que o balão caiu "nas águas puras do mar alto". Redimensiona-se assim o plano temporal em que se inscrevera a voz lírica e a partir do qual se organizam as etapas do evento celebrado no poema. A historieta arredonda-se portanto com a enunciação de que o destino do balão foi "as águas puras do mar alto", término e coroamento dos esforços em transcender das adversidades que enfrentara na rua do Sabão para ganhar os céus.

\section{O sopro lírico}

Essa primeira abordagem do poema "Na Rua do Sabão" a partir da consideração de sua base temporal pode justificar-se, como ficou dito, pelos componentes narrativos que constituem a sua "atitude enunciativa". Mesmo assim, é evidente que o significado do poema não se resume meramente em imitar uma ação completa (para valer-se aqui da conhecida formulação de Aristóteles), não se esgota portanto no ato de reconstituir um acontecimento observado num meio pobre e humilde. Se essa formação lírica possui um significado mais específico, este não se deve em primeiro lugar ao êxito do procedimento mimético, mas resultaria antes da impregnação de sua própria forma de expressão pelo mundo social observado e vivenciado. Dessa maneira, o aprofundamento na estrutura formal do texto deveria demonstrar que "Na Rua do Sabão" não se limita a representar, com elementos lírico-narrativos, a realidade social de 
uma festa num meio humilde, mas se constitui o poema, na própria materialidade lingüística, enquanto expressão estética dessa mesma realidade social.

Esta vem filtrada pela participação afetiva do poeta, uma vez que o evento foi concebido "sob um certo ponto de vista" e acolhido "dentro de uma certa tonalidade afetiva", recorrendo aos termos propostos por Alfredo Bosi em sua "Interpretação da obra literária" (13). É assim que o eu-lírico, logo após os versinhos de abertura, valoriza quanto pode, mas também com simplicidade, a feitura do balão: "O que custou arranjar aquele balãozinho de papel!” Este "custou" é índice, sem dúvida, de uma dificuldade artesanal, mas pode comportar igualmente uma alusão ao custo material que, embora pequeno, tem a pobreza como pano de fundo: "Quem fez foi o filho da lavadeira." Contrastando com os dois artigos definidos deste verso (dando a entender que pelo menos a lavadeira é personagem conhecida), o verso seguinte começa com o artigo indefinido e deixa o pequeno artesão no anonimato, mal destacando-o talvez de outros eventuais filhos da lavadeira, pois trata-se tão somente de "um que trabalha na composição do jornal e tosse muito".

Segue então a descrição de todo o processo de feitura do balão, e a qualidade desses versos livres - que mais uma vez deixam entrever a mestria de Bandeira também na arte da prosa - pode ser observada na precisão e expressividade dos verbos, substantivos, adjetivos usados tanto para a descrição como para narrar as circunstâncias que envolvem a subida do balãozinho. Pois o leitor não se cansa de admirar a precisão vocabular de Bandeira, o domínio soberano de matizes e nuanças perfeitamente concertados com o tom fundamental do poema (14). Como também se pode dizer em relação aos "Meninos carvoeiros" (com a descrição dos "burrinhos descadeirados", da "aniagem toda remendada", da "madrugada ingênua" assim como da "pequenina, ingênua miséria!", e ainda expressões como "mordendo num pão encarvoado", "encarapitados nas alimárias" etc.), os termos e as expressões presentes no poema sobre a rua do Sabão não pertencem de forma alguma à esfera lingüística dos agentes do acontecimento: "compor os gomos oblongos", "ajustar o morrão de pez ao bocal de arame", e ainda "criar fôlego", "bambear", "enfunar-se" etc. Dessa maneira, revela-se na própria dimensão lingüística trabalhada por Bandeira a profunda empatia (ou mesmo solidariedade) com o elemento humano envolvido na historieta contada, entranhando-se assim a amorosa fatura do balãozinho na imanência da linguagem, ou seja, na não menos amorosa fatura do poema "Na Rua do Sabão".

Nesse sentido - isto é, no âmbito da composição lírica, desenvolvida em correspondência com a cuidadosa composição do balãozinho -, pode-se talvez sustentar que o movimento de ascensão deste ("E foi subindo... / para longe... / serenamente...") vem como que antecipado pelo ritmo dos versos imediatamente anteriores, moldado em segmentos regidos por formas verbais em cres- 
cente expansão, como se observa em "entesou”, “enfunou-se" (expansão pelo acréscimo da partícula reflexiva) e, por fim, terceiro e mais longo segmento rítmico do verso: "e arrancou das mãos que o tenteavam." Assinalem-se ainda, quanto a este verso, dois outros recursos empregados por Bandeira para adensarlhe a coesão: por um lado, o tempo verbal no aspecto perfeito, em contraste com a fase do "cai - não cai", regida pelo imperfeito, no verso "Bambeava, tremia todo e mudava de cor"; pelo outro lado, o anasalamento, com a expressiva ocorrência das consoantes $/ \mathrm{m} / \mathrm{e} / \mathrm{n} /$, que se verifica no nível do substrato sonoro do poema. E, neste ponto, há de considerar-se que, se tal processo de sonorização por si só não é suficiente para sugerir subliminarmente o movimento ascensional do balão, o anasalamento cria ao menos forte contraste sonoro com os versos referentes à atitude da "molecada" da rua, que vêm logo em seguida e exprimem sentido oposto ao movimento mencionado. Observese ainda que a expansão conduzida pelas formas verbais no perfeito se reiterará nos versos - ou antes "semi-versos" (15) - imediatamente adjacentes, cuja prolação espraia-se em consonância com as reticências, ou pontos de suspensão, que os configuram visualmente.

A esse movimento ascensional, e também aos seus apoios rítmico-sonoros, opõe-se drasticamente a verticalização dos versos referentes à ação da "molecada", salteando-o "com atiradeiras" e depois, em semi-versos simetricamente verticalizados, "assobios" / "apupos" / "pedradas." Dominam aqui, em contraste com a brandura do anasalamento anterior, aliterações oclusivas, tanto as linguodentais $/ \mathrm{t} / \mathrm{e} / \mathrm{d} /$ quanto as bilabiais $/ \mathrm{b} / \mathrm{e} / \mathrm{p} /$, reforçando no nível da sonoridade, com a sugestão de choque própria a essas consoantes ("momentâneo-explosivas"), as resistências que se colocam à ascensão do balão. Resistências, aliás, que se intensificam no verso seguinte - separado porém por nova ocorrência do leitmotiv "Cai cai balão!" -, também apoiado em expressivas aliterações oclusivas e tendendo, com toda a intencionalidade, para a fala prosaica: "Um senhor advertiu que os balões são proibidos pelas posturas municipais" (16).

Como última observação relativa à estrutura formal do poema “Na Rua do Sabão", valeria apontar ainda para o recurso de Bandeira a correspondências ternárias. Num poema cuja opção pelo verso-livre o fez prescindir do apoio que poderia advir do esquema métrico e rímico, esse recurso contribui certamente para fundar a sua unidade formal, emoldurando também o referido jogo de contrastes. A ocorrência de tal estrutura ternária, manifesta já no leitmotiv do "Cai cai balão" (17), pode ser apontada ainda nos versos que falam da ascensão do balão e da periclitante fase inicial, apresentando, ambos os momentos, três verbos que contrastam os aspectos perfeito e imperfeito. Também os semiversos, organizados como que a sugerir, inclusive pelos pontos de suspensão, $\mathrm{O}$ movimento horizontal-expansivo, estruturam-se, da mesma forma que a verticalização brusca dos semi-versos "assobios / apupos / pedradas", em ritmo ternário. E assim também o término da história, com a tríplice ocorrência 
do verbo “caiu”, primeiro pela negativa: "Não caiu na Rua do Sabão” e, em seguida, na afirmação que se faz no verso de fecho. Mas também este apóia-se em três segmentos, os quais vão atualizando com precisão crescente a notícia da queda do balão, com o seu momento culminante no ondulamento rítmico marcado pelo extraordinário contraste entre a abertura e alteamento do /a/ assonante "nas águas do mar álto" e a vogal que se fecha e alonga na palavra (ligeiro obscurecimento na claridade do verso) que traz por fim o sentido de pureza à narrativa lírica de Bandeira: "Caiu muito longe... Caiu no mar - nas águas puras do mar alto.”

\section{A imagem e a idéia}

Com a enunciação da queda do balãozinho arredonda-se, portanto, a história que começara com a compra do papel de seda e o trabalho amoroso de uma criança pobre. Uma história de dificuldades, enfeixadas logo no verso de abertura: "O que custou arranjar aquele balãozinho de papel!", e de superação, compondo um arco que leva da Rua do Sabão (espaço em que atua a "molecada" da vila, salteando-o com gritos e pedras), até o espaço insondável das "águas puras do mar alto". Nessa passagem de um pólo a outro, o momento decisivo parece explicitar-se no centro do poema, quando o balão, vacilando até então entre a queda e a ascensão, finalmente "entesou, enfunou-se e arrancou das mãos que o tenteavam". E retornando agora à hipótese de uma correspondência entre a composição do balão e a do poema, mediadas ambas pelo trabalho amoroso, seria possível complementá-la com a observação de que é no âmbito dessa identificação - e justamente no momento decisivo em que o balão cria fôlego e se alça aos céus - que o seu pequeno artífice, "um que trabalha na composição do jornal e tosse muito", ganha um nome, acompanhado porém de importante revelação: "Como se o enchesse o soprinho tísico do José."

Também aqui o momento do reconhecimento (ou da anagnórisis, para usar o termo aristotélico), libera profunda emoção, mas não como conclusão do poema, como se pode observar, por exemplo, em relação a "Gesso", "O cacto", "O martelo" e outros poemas de Manuel Bandeira. E é na surpresa desse verso simples e delicado que se concentra subitamente toda a força simbólica que o poeta investiu nessa narrativa lírica de um acontecimento observado num meio pobre e humilde, mas alçado por fim, "pequena coisa tocante", à esfera sublime do espaço e da pureza do mar alto. Nessa perspectiva pode-se dizer então, reforçando a correspondência já assinalada, que o "soprinho tísico do José" é o que insufla vida não só ao balãozinho feito com tanto esforço e amor mas também a esse poema que, mais do que qualquer outro, exprime o gesto "amorosamente tísico" que Mário de Andrade reconheceu no amigo de correspondência. 
Nessa linha de leitura, a interpretação pode então transcender a imanência da história tematizada no poema e apreendê-la também como uma simbolização da própria existência do homem e do poeta Manuel Bandeira. Na superação dos vários obstáculos que se colocaram ao impulso ascensional do balão se vislumbraria assim a transfiguração simbólica das muitas adversidades - doença, pobreza, solidão - que marcaram essa existência, e sobre as quais Bandeira como que triunfou através da poesia, que transformou toda uma vida "que podia ter sido e que não foi" em outra que foi ficando "cada vez mais cheia de tudo", para lembrar a observação de Otto Maria Carpeaux reproduzida no final do Itinerário de Pasárgada (18). Pode-se dizer, portanto, que foi a força da poesia que possibilitou a essa existência "criar fôlego", alçar-se sobre as adversidades da "prosa da vida" e alcançar por fim as "águas puras do mar alto", nas quais também se projetará depois, como se devaneia no poema "Cantiga", o desejo de felicidade e de morte.

Observe-se ainda que o ingresso na esfera do sublime articula-se de maneira concreta, enquanto derradeira etapa da pequena história que o poema conta, com a "idéia" presente na imagem ascensional do balão, em direção portanto ao elevado, ao sublimis. O símbolo experimenta assim um significativo adensamento, podendo-se dizer então que a "idéia" entranhada na imagem do balão leva para mais além do paralelo entre o trabalho paciente e amoroso do pequeno José, pobre e tuberculoso, e o trabalho estético do poeta de Ritmo dissoluto, igualmente pobre e tuberculoso. Sempre "ativa e inatingível", conforme a formulação de Goethe, a idéia que se vislumbra no balãozinho buscando seu destino nos céus e nas "águas puras do mar alto" estaria representando também, como "revelação viva e momentânea do inescrutável", todo esforço em transcender dos obstáculos e adversidades da vida e alçar a própria existência a um sentido mais elevado, seja através de um poema, de algo como essa "pequena coisa tocante na escuridão do céu” ou de outra criação simbólica.

\section{O balão e a pipa: um aceno comparativo}

"O poeta melhor que nós todos, o poeta mais forte", diz Carlos Drummond de Andrade num dos versos de sua "Ode ao cinqüentenário do poeta brasileiro", e se há procedência nessa afirmação, se Manuel Bandeira, esse nosso lírico da Stoa, pode de fato ser considerado, à revelia da própria opinião, um poeta maior da língua portuguesa, então isto se deve também à sensibilidade com que soube modular ao longo de sua obra o tema da infância. Como testemunho avultam aqui, em primeiro lugar, as já mencionadas obras-primas "Evocação do Recife" e "Profundamente", em que a recordação lírica do próprio passado articula-se com aquele que talvez seja, por excelência, o tema magno da poética bandeiriana: a morte (19). 
Projeto Portinari

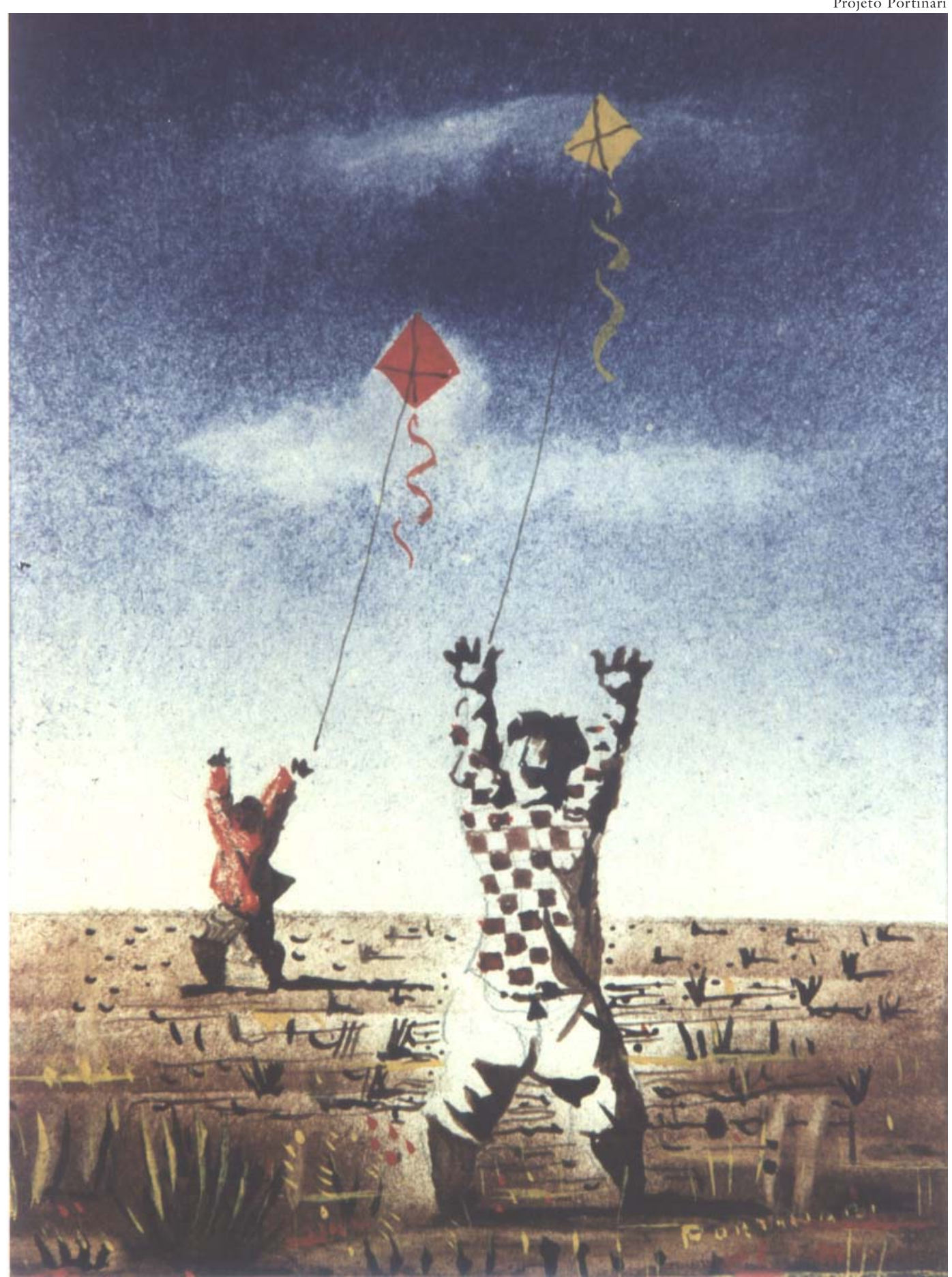

Meninos Soltando Pipas

c. 1943

Pintura a guache/papel

$16 \times 11,5 \mathrm{~cm}$

Coleção Particular - Rio de Janeiro - RJ 
Em modulações posteriores do tema, verifica-se também a tendência a arrematar o poema com uma espécie de flash, de súbita iluminação lírica dos anos de meninice, como se o poeta já maduro ou mesmo envelhecido se descobrisse, em percepção instantânea, como sendo ainda o menino que - como está dito em "Versos de Natal" - "todos os anos na véspera do Natal / Pensa ainda em pôr os seus chinelinhos atrás da porta." São versos da Lira dos cinqüent'anos, de onde poderíamos extrair ainda outras ilustrações para esse procedimento: enquanto o poema "Peregrinação" arredonda-se com a evocação final do " - Mim daqueles tempos!", em "Velha Chácara" vemos levantar-se inesperadamente, no verso de fecho, o único sobrevivente das ruínas do passado: " - Mas o menino ainda existe." Com semelhante efeito de pointe é contemplada também a "Elegia de Verão", esta de Opus 10, mediante a reivindicação final ao mesmo tempo divertida e pungente: "Dêem-me as cigarras que eu ouvi menino."

Diferentemente de todos esses poemas, "Na Rua do Sabão" e "Meninos Carvoeiros" adentram o universo da infância não pela presentificação epifânica da experiência individual, isto é, a plenitude mítica de quatro anos vividos em extinta Tróada recifense, mas pelo lado sombrio do trabalho infantil. Longe, porém, de pretender denunciar um sistema social que condena à miséria a maior parte de suas crianças, privando-as assim de uma vivência digna da infância, esses dois poemas de Ritmo dissoluto exprimem antes de mais nada a empatia do poeta com os pequenos trabalhadores que contempla: os "adoráveis carvoeirinhos" que trabalham como se estivessem brincando, e o pequeno José, filho tuberculoso de lavadeira e empregado de tipografia. O olhar sublimador do poeta parece comprazer-se em surpreender a capacidade das crianças de extrair momentos lúdicos ao pesado fardo do trabalho, transfigurando-se desse modo a opressão real em "pequenina, ingênua miséria".

Mas seria justo cobrar de Manuel Bandeira uma postura que mesmo um dos mais veementes teóricos do engajamento social do escritor, o Jean-Paul Sartre de Qu'est-ce que la littérature?, em momento algum exige do poeta lírico? Ainda que seja a indignação social ou o ódio político a dar origem ao poema, o verdadeiro lírico, observa Sartre, jamais estará se utilizando das palavras como faria o prosador, mas sim entregando-se incondicionalmente à linguagem (20), numa penetração surda "no reino das palavras", como talvez se possa dizer recorrendo a verso drummondiano do poema "Procura da poesia".

Ao problema do trabalho infantil, tão vergonhoso quanto emblemático de nossa longa história de opressão e injustiças (21), Bandeira dispensa um tratamento simbólico e, em conseqüência, os verdadeiros questionamentos que "Na Rua do Sabão" ou "Meninos Carvoeiros" possam suscitar já terão encontrado resolução na dimensão estética em que se inscrevem enquanto poemas. No entanto, seria lícito contemplá-los por um instante a partir da própria realidade tematizada (e liricamente transfigurada). Também não deixaria de ser le- 
gítimo, para efeito de comparação e contraste, lembrar outras tematizações líricas da infância, e mesmo as que mais se afastam da poética de Bandeira. Dada a magnitude dessa temática na história da literatura, possibilidades praticamente ilimitadas abrir-se-iam aqui à perspectiva comparativa. Podemos lembrar, por exemplo, alguns momentos da poesia de Bertolt Brecht, com sua postura social tão diferente da bandeiriana, mas que tem na expressão despojada, em que a simplicidade dissimula não raro a complexidade da elaboração lingüística (um lírico contemplado com a "integridade da linguagem”, como observou Adorno) uma zona de afinidades com o poeta brasileiro.

Ao contrário do autor de "Evocação do Recife" e de tantos outros líricos para quem a "nossa infância perdida", voltando à citada formulação de Schiller, "para sempre permanece como aquilo que nos é mais precioso", as poucas vezes em que Brecht fala da infância, ele o faz em sentido irônico: "O belo tempo de criança, que nunca mais volta", lê-se por exemplo num dos versos do poema "Coisas que são ditas às crianças", do ciclo "Canções Infantis 1937". Após o período nacional-socialista e os anos de guerra, impõe-se em sua poesia a tendência a falar em primeiro lugar sobre e para as gerações que poderiam construir uma sociedade mais justa e solidária, e um momento culminante dessa tendência realiza-se nas quatro pequenas estrofes do "Hino Infantil" (1950), que encontrou na música de Hans Eisler uma criação congenial. Vendo pela primeira vez, nas jovens gerações da República Democrática Alemã, possibilidades reais para a concretização das esperanças no futuro socialista, Brecht formula, em novo ciclo de canções infantis, uma espécie de utopia da infância, retomando de certa forma as aspirações que exprimira em 1939 no poema "Aos que vierem depois de nós".

O fato de dirigir-se o poeta alemão, em seus ciclos de canções infantis, diretamente às crianças - isto é, com imagens, linguagem e ritmo em sintonia com essa intenção - constitui evidentemente uma diferença fundamental em relação aos poemas de Ritmo dissoluto voltados para o tema da infância pobre. No entanto, traço comum a ambos os poetas é o recurso a elementos intimamente associados ao universo lúdico da criança, símbolos como o "balão" ou a "pipa", que compõem um espaço de afinidades justamente no movimento ascensional - ou na esfera do sublime, onde soa também, muito acima desta "baixa vida terrena" e no "firmamento azul", "vizinho do trovão" e próximo ao "mundo das estrelas", o "Sino" de Schiller, como comenta Hegel em suas explanações sobre o lírico (22).

Brecht intitulou de "Pequena canção do pós-guerra" duas estrofes de quatro versinhos que integram um novo ciclo de canções infantis escritas em 1950: a primeira gira no ritmo célere de um pião que tem agora, em meio aos trabalhos de limpeza dos escombros e reconstrução da cidade, toda a rua à sua disposição; na segunda é uma pipa, espécie também de "pequena coisa tocan- 
te" num céu agora em paz, que pode alçar vôo: "Voa, pipa, voa! / Não há mais guerra no céu. / E se arrebenta a linha, então a coisinha voa / Por cima de Moscou até Pequim. / Voa, pipa, voa!”

Em outro poema infantil, "Canção da pipa” (que segue aqui em tradução literal), celebra-se também um movimento ascensional, submetido porém ao controle humano e, assim, com características diferentes do impulso que, no delicado verso de Bandeira, emana do "soprinho tísico do José":

\section{Canção da Pipa}

Voa, pequena pipa, voa,

Eleva-te com vontade aos ares

Empina, pequena coisa azul, empina,

Sobre a nossa catacumba de casas!

Se nós te seguramos pela linha

Tu te manténs nos ares

Escravo dos sete ventos

A levantar-te os obrigarás.

E nós ficamos a teus pés!

Voa, voa, pequeno ancestral

De nossos grandes aeroplanos

Olha ao teu redor para saudá-los!

Linguagem, ritmo, imagens assim como a estrutura rímica do original moldam-se, como observado, em consonância com o mundo-de-vida das crianças, cuja superioridade em relação ao mundo dos adultos revela-se na imagem da pipa empinando sobre a "catacumba de casas" e saudando orgulhosa os "grandes aeroplanos". E também não seria difícil reconhecer a visão que o poeta alemão insuflou a seu ciclo de canções infantis: "Escravo dos sete ventos / A levantar-te os obrigarás" não está celebrando outra coisa senão o domínio do homem - transposto porém ao espaço lúdico (o menino empinando a pipa) sobre as forças da natureza (os "sete ventos").

E neste ponto abre-se imensa distância em relação ao poeta brasileiro em cujas apreciações políticas podemos reconhecer por vezes as marcas de um aristocratismo não muito diferente daquele que Brecht costumava ironizar em Rainer Maria Rilke e que o próprio Sartre, já no livro mencionado, disseca em Flaubert com um prazer indisfarçável. E isso sem falar ainda nas invectivas anticomunistas que se infiltraram na bela prosa do Itinerário de Pasárgada, a primeira das quais se arrogando o direito de desqualificar um engajamento de 
Paul Éluard, o antigo companheiro de sanatório em Davos que, com seu talento "bastante pessoal e tão aristocrático", jamais deveria sujeitar-se "à boçal estética imposta pelo comunismo russo aos seus escravos". Palavras estranhas de Bandeira, que se fecham a qualquer possibilidade de crítica dialética às deformações do socialismo real e que em seu tom furibundo tanto contrastam com o espaço generoso que abriu a Alberto Childe, "em tudo um homem de direita", e de quem também, nas palavras que arrematam a evocação, "poderia dizer que era um puro". No entanto, foi justamente num trecho dessas memórias de Pasárgada que se pôde colher ilustração das mais expressivas para a reflexão de Marx citada na primeira parte do ensaio.

Mas estas considerações finais não poderiam ter outra finalidade senão fazer ressaltar com mais intensidade a dimensão viva que, para além das posturas ideológicas, pulsa nos grandes textos líricos. E que valha aqui, mais uma vez, a recomendação de vigilância que faz Adorno, em seu texto sobre "lírica e sociedade", com relação ao conceito de "ideologia": "Ela se manifesta no malogro da obra de arte, no que esta tem em si de errado, e é alvo da crítica". E, em seguida, a advertência quanto ao perigo de se imputar a acusação de ideologia a obras de arte "que têm sua essência no poder de configurar e, somente através desse poder, na capacidade de conciliação tendencial de contradições fecundas da existência real” (23).

Não deixa de ser verdade que poemas como "Meninos carvoeiros" ou “Na Rua do Sabão" não questionam (e nem sequer roçam) a questão social de que conseguem extrair lirismo tão pungente, isto é, a miséria que atinge as crianças e fomenta a exploração do trabalho infantil - realidade historicamente vergonhosa, mas que hoje, em funesta conjunção com as diversas formas de violência que grassam na sociedade brasileira, vem atingindo níveis sempre crescentes de barbárie. O poeta de Ritmo dissoluto que se voltou então às crianças excluídas e exploradas não acusa nem denuncia, como buscará fazer muitos anos depois no poema "O bicho", no volume Belo Belo, conferindo expressão à perplexidade diante da miséria e da fome que animalizam o homem. Tampouco poder-se-ia vislumbrar, nessas tematizações líricas da infância pobre, a "emoção social" que emana, na visão do próprio Bandeira, de um poema como "O martelo", vigorosa celebração do trabalho cotidiano de um ofício humilde.

Acima, contudo, de eventuais omissões e insuficiências que se possam apontar nos poemas aqui considerados, avulta o gesto amorosamente solidário que Bandeira estende aos carvoeirinhos ou ao tísico José - os meninos trabalhadores que, com sua ética ingênua, com sua pequena humanidade sofrida, animam esses poemas, suscitando nos leitores o sentimento expresso pela primeira vez na citada carta de Mário de Andrade. Se fazer "versos de guerra", como está dito em "Testamento", nunca esteve ao alcance de Manuel Bandeira, ele soube todavia abrir muitos caminhos para levar aos seus semelhantes - mo- 
dulada em sons, ritmos e imagens - a "palavra fraterna" que soa no final do Itinerário de Pasárgada como a grande mensagem de sua obra. Não se pode exigir de poemas como "Meninos carvoeiros" ou "Na Rua do Sabão" mais do que a empatia sublime, o gesto enlevado e ético que, acima de todas as contradições da existência real, irmana o grande poeta lírico aos seus pequenos "espantalhos desamparados" e que ao mesmo tempo faz ressoar em muitos de seus leitores a aspiração por um estado social mais justo e solidário.

\section{Notas}

1 Pobre e breve de um lado, mas evocada como uma felicidade perdida para sempre: também para essa caracterização paradoxal da infância vale certamente a observação de Walter Benjamin de que "podemos ler durante muito tempo as histórias de animais de Kafka sem perceber que elas não tratam de seres humanos". (Franz Kafka: a propósito do décimo aniversário de sua morte. In Magia e técnica, arte e política, São Paulo, Brasiliense, 1985, p. 147. Tradução de Sérgio Paulo Rouanet.)

2 Lembre-se aqui a formulação de Alfredo Bosi referente às imagens citadas: "Através das águas do lago passava a luz, aquele 'ouro da manhã' que brilha na página de abertura como a eterna metáfora da infância" (O Ateneu - Opacidade e destruição. In Céu, inferno, São Paulo, Ática, 1988, p. 35.)

3 Friedrich Schiller, Poesia ingênua e sentimental, São Paulo, Iluminuras, p. 44; tradução e estudo de Márcio Suzuki. A observação citada é desdobrada por Schiller algumas linhas adiante: "É erro acreditar que a mera representação do desamparo seja aquilo que, em certos momentos, nos detém com tanta emoção junto às crianças. (...) Não ficamos comovidos porque olhamos para a criança do alto de nossa força e perfeição, mas porque da limitação de nosso estado, que é inseparável da determinação uma vez atingida por nós, elevamos o olhar para a determinabilidade ilimitada e para a inocência pura da criança, e em tal instante nosso sentimento está muito visivelmente mesclado a uma certa melancolia para que se possa desconhecer a sua fonte."

4 Essa reflexão encontra-se na Introdução ao volume Grundrisse der Kritik der politischen Ökonomie, Berlim, Dietz Verlag, 1983, v. 43 (Ökonomische Manuskripte 1857/ 1858), p. 44-45. Entre os vários comentários a esse texto de Marx, citem-se por exemplo Georg Lukács (Introdução a uma estética marxista, capítulo A arte como autoconsciência do desenvolvimento da humanidade, Rio de Janeiro, Civilização Brasileira, 1970, p. 269); ou ainda, entre nós, Alfredo Bosi ( $O$ ser e o tempo da poesia, capítulo Poesia resistência, São Paulo, Companhia das Letras, 2000, p. 163 227). Emil Staiger, em seus Conceitos fundamentais da poética (Estilo épico, $6^{\circ}$ segmento), estabelece igualmente uma relação entre a infância individual e o estágio histórico que se vislumbra na epopéia homérica.

5 Manuel Bandeira, Seleta de prosa (org. Júlio C. Guimarães), Rio de Janeiro, Nova Fronteira, 1997. O Itinerário de Pasárgada encontra-se reproduzido às páginas 295360 (citação à p. 297). 
6 Como que impregnada de um presente eterno é também a dimensão temporal que evoca Hermann Hesse na segunda das cinco estrofes do seu poema Recordação, de janeiro de 1945: "O mais elevado seria: viver / Em eterno presente. / Mas essa graça só foi dada / Às crianças e a Deus."

7 A análise e interpretação desse poema encontra-se no capítulo A festa interrompida, que abre a terceira parte do livro Humildade, paixão e morte (São Paulo, Companhia das Letras, 1990, p. 201-232). A idéia da morte como sono e a presentificação epifânica dos que adormeceram permitiriam lembrar aqui o poema Die Entschlafenen, em que Hölderlin recorda (no sentido etimológico do verbo, afim ao correspondente alemão erinnern) "os adormecidos": "Um dia fugaz eu vivi e cresci entre os meus, / Um após outro já me adormece e vai fugindo pra longe. / E no entanto, vós que dormis, 'stais-me acordados cá dentro do peito, / $\mathrm{Na}$ alma parente repousa a vossa imagem que foge. / E mais vivos viveis vós ali, onde a alegria do espírito divino / A todos os que envelhecem, a todos os mortos rejuvenesce" (Tradução de Paulo Quintela: Hölderlin - Poemas, Coimbra, Atlântida, 1959, p. 249)

8 Op. cit., p. 328.

9 Op. cit., p. 322.

10 "E tu? que fazes? Manda-me alguns versos teus. Não publicas algum livro proximamente? Fala-me de teus projetos. Se Klaxon sair mais uma vez, permitirás a colocação do poema 'Rua do Sabão' nela? Sim. Obrigado.” In Correspondência - Mário de Andrade \& Manuel Bandeira. São Paulo, EDUSP/IEB, 2000. Organização, introdução e notas de Marcos Antonio de Moraes. A carta em questão encontra-se reproduzida às páginas 92-94, e a datação traz apenas a indicação do dia 22, mas o complemento de mês e ano é atestado em nota do organizador da edição (citação seguinte à página 96.)

11 Op. cit., p. 100. Significativamente, Mário faz com que o seu "questionamento" do estado de espírito sugerido por Bandeira seja precedido de uma versão anterior do poema XVII de Losango cáqui, que conclui com o verso: "A própria dor é uma felicidade!” A observação de Bandeira, em carta de 27 de julho de 1923, que suscitou a discordância do amigo, refere-se a um retrato que tirara 10 anos atrás e que anexava então à carta: "Mas não é o Manuel Bandeira de hoje. É o Manuel Bandeira da Cinza das horas. É de um tempo em que eu era muito mansamente e muito doloridamente tísico. Hoje sou ironicamente, sarcasticamente tísico. Naquele tempo vivia do dinheiro de meu pai e do carinho dele e de minha mãe e de minha irmã. Hoje vivo da caridade do Estado e como ao Brás Cubas o que me conforta é não transmitir a ninguém o legado da minha miséria" (op. cit., p. 97).

12 Em seu ensaio A interpretação da obra literária, Alfredo Bosi chama a atenção para o significado dos conceitos de "tom" e "perspectiva" na organização da obra literária. Veja-se em especial a reflexão desenvolvida no tópico Perspectiva e tom - in Céu, inferno, São Paulo, Ática, 1988, p. 274-287.

13 Op. cit., p. 276. Na perspectiva hermenêutica exposta no ensaio, algo só se tornaria um evento para o sujeito "quando este o situa no seu aqui e o temporaliza no seu 
agora; enfim, quando o sujeito o concebe sob um certo ponto de vista e o acolhe dentro de uma certa tonalidade afetiva." Mais adiante (p. 283), outra formulação enfatizando a relevância hermenêutica dos conceitos de "tom" e "perspectiva": "A afinação do tom e a busca da perspectiva exata iluminam os dados particulares".

14 Quanto a este ponto, valeria lembrar a observação de Davi Arrigucci Jr. referente à qualidade da "prosa imitada" bandeiriana nos versos livres do poema $\mathrm{O}$ cacto: "O controle perfeito da nuance exata que se busca, supervisionando o andamento do discurso em percurso contínuo e linear, ajustado precisamente ao assunto, revela de fato a atitude do exímio prosador". O cacto e as ruinas, São Paulo, Duas Cidades / Editora 34, 2000, citação à página 82.

15 No extraordinário ensaio Como fazer versos?, que não apenas sistematiza a sua concepção de poesia mas também descortina ao leitor vários detalhes de sua própria "oficina" poética, Maiakóvski fundamenta o emprego de semi-versos, ou "semilinhas", enquanto procedimento que confere maior firmeza e clareza ao ritmo e ao sentido do segmento do poema em que se inserem. In Boris Schnaiderman, $A$ poética de Maiakóvski, São Paulo, Perspectiva, 1971, p. 167-219 (sobre o assunto, ver p. 199).

16 Na versão manuscrita enviada a Mário de Andrade, lê-se "obtemperou” no lugar de "advertiu". Embora rico em consoantes oclusivas, o termo, além de trazer ao verso um preciosismo que não existe em "advertir", estaria amainando o rigor da proibição levantada por esse porta-voz das "posturas municipais". Lembremos também que na versão manuscrita dos "Meninos carvoeiros", Bandeira usa erroneamente o termo "chouteira" para designar o instrumento com que os "burrinhos descadeirados" vão sendo tocados. Mário chama a atenção do amigo para o erro e recomenda a substituição do termo, o que também se dá em prol de uma maior simplicidade: "E vão tocando os animais com um relho enorme."

17 Observe-se também, no poema "Meninos carvoeiros", a tripla ocorrência do verso “- Eh, carvoero!”, que transforma em leitmotiv rítmico a exclamação (ou pregão) dos meninos a caminho do trabalho.

18 Na mencionada edição do Itinerário (nota 5) lê-se "poderia" em lugar de "podia", como de fato está no segundo verso do poema Pneumotórax: "A vida inteira que podia ter sido e que não foi".

19 É também a presença da morte que encerra as evocações do poema Infância, fecho por sua vez do volume Belo belo. O poema expõe o esforço consciente do poeta já sexagenário em fixar as suas mais "velhas reminiscências", começando com as primeiras impressões em Petrópolis, aos três anos de idade. Tem-se porém a impressão de que Bandeira, sem o transporte da revelação epifânica, não consegue de fato romper "os ruços definitivos do tempo", restando lacunar esse esforço da memória em reconstituir acontecimentos da infância.

20 A diferenciação entre a atividade do lírico e a do prosador é estabelecida por Sartre no capítulo O que é escrever?, o primeiro do livro. Ao contrário do prosador que, ao expor os seus sentimentos, busca esclarecê-los, o poeta, na argumentação sartriana, 
deixa de reconhecer os sentimentos e paixões que virtualmente deram ensejo ao poema, pois os entrega à livre ação das palavras, que deles se apoderam e os metamorfoseiam. As palavras, no poema, deixam assim de significar, de remeter a realidades exteriores, como seria próprio do signo; elas não mais significam, mesmo aos olhos do poeta: "A emoção se tornou coisa, passou a ter a opacidade das coisas; é turvada pelas propriedades ambíguas dos vocábulos em que foi confinada" (citado conforme a edição brasileira: Que é a literatura? São Paulo, Ática, 1993, trad. de Carlos Felipe Moisés.). É nos capítulos posteriores (Por que escrever? e Para quem se escreve?) que Sartre irá precisar, em bases filosóficas, o seu conceito de littérature engagée. Somente ao romancista (e ao prosador de modo geral) colocase portanto a exigência de dotar o universo criado de um movimento que leva à superação das injustiças que esse universo encerra. As implicações que esse movimento tem para o leitor não são evidentemente extensíveis ao leitor de poesia: "Quanto a mim, que leio, se crio e mantenho em existência um mundo injusto, não posso fazê-lo sem que me torne responsável por ele. E toda a arte do autor consiste em me obrigar a criar aquilo que ele desvenda - portanto em me comprometer. Eis que nós dois arcamos com a responsabilidade pelo universo. E precisamente porque esse universo é sustentado pelo esforço conjugado de nossas duas liberdades, e porque o autor tentou, por meu intermédio, integrá-lo ao humano, é preciso que o universo apareça verdadeiramente em si mesmo, em sua massa mais profunda, como que atravessado de lado a lado e sustentado por uma liberdade que tomou por fim a liberdade humana (...)” (p. 50).

21 Sobre esse assunto, vejam-se os estudos enfeixados no volume História das crianças no Brasil, organizado por Mary Del Priore (São Paulo, Contexto, 1999), em especial a contribuição de Irma Rizzini: Pequenos trabalhadores do Brasil (p. 376-406).

22 Ästhetik, Berlim e Weimar, Aufbau-Verlag, 1976. (A referência à Canção do Sino de Schiller encontra-se no $3^{\circ}$ capítulo, A Poesia, da seção dedicada às Artes Românticas - v. 2, p. 502).

23 Lírica e sociedade, tradução de Rubens Rodrigues Torres Filho, com assessoria de Roberto Schwarz. In Textos escolbidos, São Paulo, Abril, 1980, p. 193-208, citação às p. 194-195.

Marcus V. Mazzari é professor de teoria literária na USP e autor do livro Romance de formação em perspectiva histórica (Ateliê, 1999). 